\title{
Assessment of Water Requirement and Irrigation Schedule for Right Bank Canal Command of Shahid Veer Narayan Singh Dam using CROPWAT 8.0
}

\author{
Janhavi*, Jitendra Sinha, Pushpendra Kumar Singh and M. P. Tripathi
}

University of Agricultural and Horticultural Sciences, Shimoga-577204, Karnataka, India

*Corresponding author

\section{Ke y w o r d s \\ Irrigation scheduling, Irrigation efficiency, Discharge, Water requirement etc. \\ Article Info \\ Accepted: \\ 20 November 2019 \\ Available Online: \\ 10 December 2019}

\section{A B S T R A C T}

Irrigation Scheduling is a prime requirement for optimizing the use of water resources in irrigated agriculture. The majority of irrigation projects in India perform at a low overall efficiency of $30 \%$ (Sarma and Rao, 1997), which provides an opportunity for meeting the increasing water demands by adopting efficient methods of water management. The National Commission on Integrated Water Resources Development (NCIWRD, 1999) has projected that India's surface irrigation systems will work at only 40, 50 and $60 \%$ efficiency levels in 2010, 2025 and 2050, respectively. This demands for optimization of canal irrigation Scheduling. With this in view the present study has been carried out for kharif crop in the Right bank canal command area of Shahid Veer Narayan Singh Dam. In present study after analyzing water requirements during the entire growth period of Paddy crop (Main Kharif crop of the study area), data on seasonal water discharge, soil data, meteorological data have been collected and irrigation scheduling of Paddy crop was carried out through the application of CROPWAT 8.0 Software with the aim to maximize crop cultivation area and Optimum utilization of Water resources. The designed discharge capacity of water in the study area of Right bank canal at head is 6.65 cumecs and after analysis it was found that in practice $19.92 \mathrm{Mm}^{3}$ of water is supplied in the study area. During the Kharif season, crop water requirement (CWR) scheme supply requires only $8.95 \mathrm{Mm}^{3}$ after optimization through CROPWAT 8.0 software, which is only $44.92 \%$ of actual supplied water. Therefore saving of $5.01 \mathrm{Mm}^{3}$ of water is supplied as surplus quantity which can be saved by reducing the canal regulation days.

\section{Introduction}

Water availability are reducing due to climatic changes occurring in the environment on the other hand water demands are increasing rapidly and as a result of that, the availability of water for agriculture is getting limited. Efficient agriculture water use is very low in India and due to that, there is an immense need to improve and manage it. Irrigation is mainly dependent on various sources, including the Rainfall, availability of canal water and ground water. Water use efficiencies are comparatively less in canal command areas than command areas that depend on groundwater. In India, most of canal command areas are suffering from either excess or deficit water supply as a result there is a broad difference between irrigation demand and supply. Generally, under open 
canal conveyance and surface irrigation methods less than half of the water released reaches the field.

The majority of irrigation projects in India perform at a low overall efficiency of 30\% (Sarma and Rao, 1997), which provides an opportunity for meeting the increasing water demands by adopting efficient methods of water management. The National Commission on Integrated Water Resources Development (NCIWRD, 1999) has projected that India's surface irrigation systems will work at 40, 50 and $60 \%$ efficiency levels in 2010, 2025 and 2050 , respectively. Another huge problem that is rising in the present is the increasing need for alternative demands for water supply due to urbanization and industrialization.

These demands are creating more pressure on water resources specially on irrigation sector. Although the farmers intend to use the maximum water for irrigating the crop, this method even in the case of no limitation, doesn't seem to be logical. Under such conditions, it is required that the Water Use Efficiency (WUE) should be optimized in the field (Moutonett, 2002). Therefore, at present irrigation sector is facing the challenge of maximizing irrigation efficiency. Hence, in order to enhance the irrigation efficiency, estimation of irrigation demand is really important coupled with efficient management of water in the canal command area before releasing the water to the crops.

Looking to the all above points present study was carried out to estimate the Net Irrigation requirement in the right bank canal command of Shahid veer Narayan Singh Dam. At present traditional allocation system is followed in command area of Shahid Veer Narayan Singh Dam. Effective and efficient usage of the available water resources to meet the irrigation demand, irrigation scheduling plays a main key role. Irrigation Scheduling is the process of supplying the needed amount of water for crops at the most appropriate time so that soil water content never falls below the management allowable depletion level to avoid the crop stress, thus maximizing the yield (Rao and Trivedi, 2012; Singh et al., 2016). CROPWAT 8.0 software was used for analyzing water requirements during the entire growth period of crop, also an irrigation schedule was estimated with the help of CROPWAT 8.0 software. CROPWAT 8.0 for Windows is a computer programme for the computation of crop water requirements and irrigation requirements from existing climatic and crop data.

Furthermore, the program allows the development of irrigation schedules for different management conditions and the calculation of scheme water supply for varying crop patterns. The present study was carried out for the kharif season only.

\section{Materials and Methods}

\section{Study area}

Shahid Veer Narayan Singh Dam is Situated under the Mahanadi basin of Chhattisgarh Plains at $21^{\circ} 11^{\prime} 50^{\prime \prime} \mathrm{N}$ to $82^{0} 10^{\prime} 40^{\prime \prime} \mathrm{E}$. Location of the dam is Shown in figure 1. The Government of Chhattisgarh Water Resources Department, started the project of Shahid Veer Narayan Singh Dam in 1976-77 and completed it in the year 1998-99. The purpose of the Dam is to irrigate the command area of about 24876.16 $\mathrm{Ha}$ in 52 villages of Mahasamund District of Chhattisgarh. River Passes through almost plain areas of Chhattisgarh. The catchment area of the Shahid Veer Narayan Singh Dam is 317.17 Square Kilometers. The topography of the area is flat. The present study is focused on the estimation of water requirement and irrigation schedule with respect to crop grown in the study area. 


\section{Data collection}

\section{Cropping pattern}

Cropping pattern data was collected from Department of Agriculture, Mahasamund District.

In study area during kharif season mainly paddy crop is grown as a major crop covering most of the canal command area of Shahid Veer Narayan Singh Dam.

\section{Climate Data}

Daily Climate data pertaining to rainfall, minimum/maximum temperature, relative humidity, sun shine hours etc. of the Mahasamund station (Latitude $21^{0} 11^{\prime} 50^{\prime \prime} \mathrm{N}$ and Longitude $82^{\circ} 10^{\prime} 40^{\prime \prime} \mathrm{E}$ ) in which study area is located were downloaded from http://power.larc.nasa.gov/cgi-bin/cgiwrap/ solar/agro.cgi for 11 years duration (2005 to 2015) and average climatic data and evapotranspiration calculated by CROPWAT 8.0 software of the study area are presented in Table 1.

\section{Soil data}

Soil data of the study area were collected from Department of Soil Science and Agricultural chemistry, IGKV, Raipur.

\section{Canal data}

Canal hydraulic and statistical data were collected from water resources department of Mahasamund district, Chhattisgarh.

\section{Application of CROPWAT 8.0 Software}

Inbuilt Computer programme are very useful for accessing database for climatic and crop characteristics to allow instant determination of irrigation water requirements. On the basis of averaged climatic conditions experienced in the study area for a significant length of time an indicative Schedule can be worked out.

CROPWAT 8.0 is meant as a practical tool to carry out standard calculations for reference evapotranspiration, crop water requirements and crop irrigation requirements and more specifically the design and management of irrigation schemes (Martin et al., 1993) CROPWAT 8.0 is one of the models that are being extensively used in the field of water management throughout the world.

For Determination of CWR and irrigation scheduling CROPWAT 8.0 requires meteorological data, crop data and soil data as an input in the programme.

The whole process is facilitated by number of windows opening one after the other to let user feed a required set of particular data.

The calculation modules of CROPWAT 8.0 are:

CWR - for calculation of Crop Water Requirements

Schedules (dry crop or rice) - for calculation of irrigation schedules

Scheme - for calculation of scheme supply based on a specific cropping pattern.

\section{Reference crop evapotranspiration $\left(\mathbf{E T}_{\mathbf{0}}\right)$}

A meeting held in between the experts of consultation group have decided and recommended that MODIFIED Penman Monteith method for calculation of reference evapotranspiration $\left(\mathrm{ET}_{0}\right)$. The monthly $\mathrm{ET}_{0}$ values data was computed using Modified Penman method, (Doorenbos and Pruitt, 1977) utilizing average climatic data presented in Table 1. 
Fig.1 Location map of Shahid Veer Narayan Singh Dam along with right bank canal command

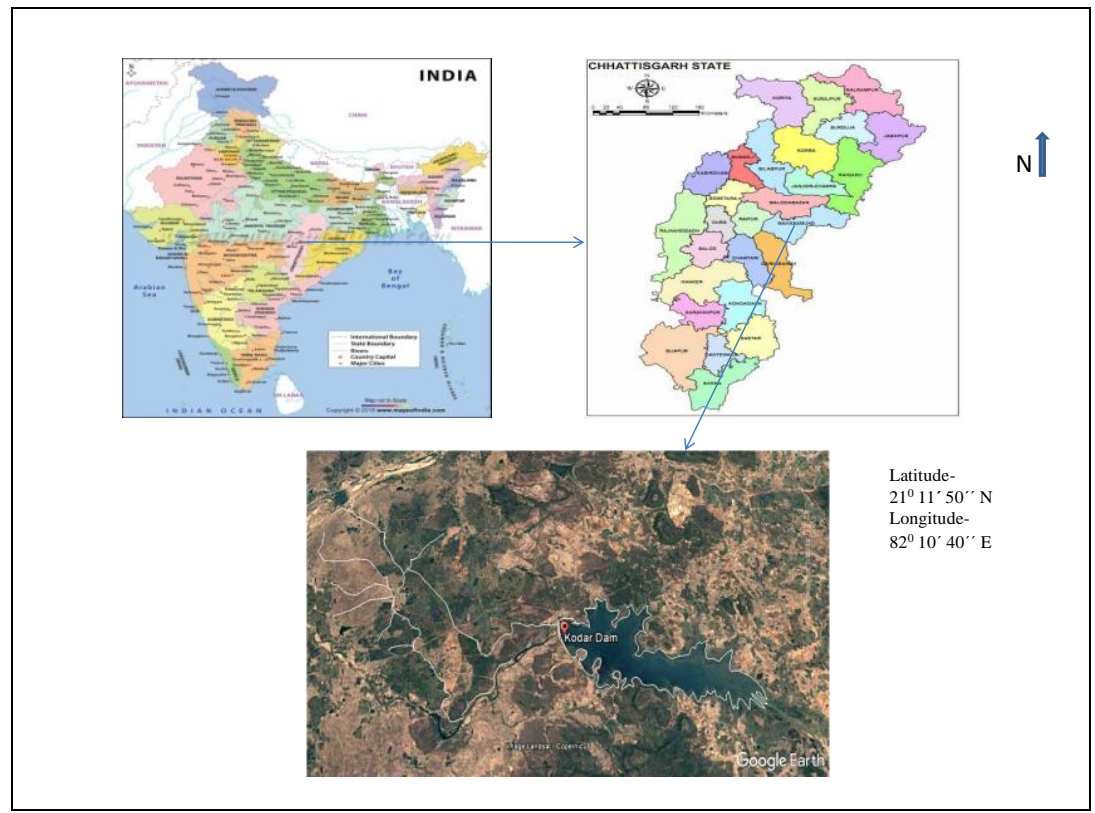

Table.1 Monthly Average climatic data of Mahasamund District

\begin{tabular}{|c|c|c|c|c|c|c|}
\hline Month & $\begin{array}{c}\text { Max. } \\
\text { Temp. } \\
\left({ }^{\circ} \mathbf{C}\right)\end{array}$ & $\begin{array}{c}\text { Min. } \\
\text { Temp. }\left({ }^{\circ} \mathbf{C}\right)\end{array}$ & $\begin{array}{c}\text { Humidity } \\
(\mathbf{\%})\end{array}$ & $\begin{array}{c}\text { Wind } \\
\text { Speed } \\
(\mathbf{k m} / \mathbf{h r})\end{array}$ & $\begin{array}{c}\text { Sun Shine } \\
(\mathbf{h r s})\end{array}$ & $\begin{array}{c}\mathbf{E T}_{\mathbf{0}} \\
(\mathbf{m m} / \mathbf{d})\end{array}$ \\
\hline January & 23.86 & 9.86 & 65.27 & 2.09 & 8.3 & $\mathbf{3 . 8 9}$ \\
\hline February & 26.55 & 11.73 & 56.43 & 2.05 & 8.7 & $\mathbf{3 . 6 7}$ \\
\hline March & 35.21 & 19.01 & 35.57 & 2.34 & 9 & $\mathbf{3 . 4 9}$ \\
\hline April & 39.28 & 24.83 & 29.33 & 3.20 & 8.8 & $\mathbf{2 . 9 1}$ \\
\hline May & 43.53 & 29.23 & 22.93 & 3.37 & 5.8 & $\mathbf{2 . 0 9}$ \\
\hline June & 36.78 & 26.77 & 54.14 & 4.35 & 3.5 & $\mathbf{2 . 0 9}$ \\
\hline July & 32.07 & 24.69 & 76.29 & 4.23 & 4 & $\mathbf{2 . 1 9}$ \\
\hline August & 30.86 & 24.07 & 82.68 & 3.48 & 5.3 & $\mathbf{2 . 7 8}$ \\
\hline September & 33.57 & 21.74 & 54.76 & 3.08 & 7.7 & $\mathbf{3 . 5 9}$ \\
\hline October & 33.27 & 21.54 & 56.34 & 2.96 & 8.1 & $\mathbf{4 . 3 0}$ \\
\hline November & 30.57 & 16.86 & 57.78 & 2.07 & 8.3 & $\mathbf{4 . 4 0}$ \\
\hline December & 29.30 & 14.27 & 58 & 2.05 & 7.2 & $\mathbf{4 . 0 3}$ \\
\hline Average & $\mathbf{2 3 . 8 6}$ & $\mathbf{9 . 8 6}$ & $\mathbf{6 5 . 2 7}$ & $\mathbf{2 . 0 9}$ & $\mathbf{8 . 3}$ & $\mathbf{3 . 2 9}$ \\
\hline
\end{tabular}

Table.2 Crop coefficient values of paddy for its different growth stages

\begin{tabular}{|l|c|c|c|c|c|c|}
\hline & Crop & \multicolumn{5}{|c|}{ Crop Growth Stage } \\
\hline & & Initial & Development & Middle & Late & Harvest \\
\hline $\mathbf{1}$ & Paddy (Rice) & $1.1-1.15$ & $1.1-1.15$ & $1.1-1.3$ & $0.95-1.05$ & $0.95-1.05$ \\
\hline
\end{tabular}

Sources: Jain irrigation and Research 
Table.3 Irrigation scheduling of canal release by CROPWAT 8.0 software

\begin{tabular}{|c|c|c|c|c|c|c|c|c|c|c|}
\hline \multirow[t]{2}{*}{$\begin{array}{l}\text { Month/ } \\
\text { Crop Variety }\end{array}$} & \multirow{2}{*}{$\begin{array}{c}\text { Proposed } \\
\text { Irrigated } \\
\text { area (ha) }\end{array}$} & \multicolumn{3}{|c|}{$\begin{array}{l}\text { Average Canal supply } \\
\text { in practice }\end{array}$} & \multicolumn{3}{|c|}{$\begin{array}{l}\text { CWR scheme supply, through } \\
\text { CROPWAT8 model }\end{array}$} & \multicolumn{2}{|c|}{$\begin{array}{l}\text { Requirement } \\
\text { supply }\end{array}$} & \multirow{2}{*}{$\begin{array}{c}\text { Remarks } \\
\text { Total } \\
\text { surplus }\end{array}$} \\
\hline & & $\begin{array}{l}\text { Avg. } \\
\text { Dis. }\end{array}$ & $\begin{array}{c}\text { Durati } \\
\text { on }\end{array}$ & Qty. & $\begin{array}{c}\text { Net } \\
\text { Scheme } \\
\text { Irri. Req. }\end{array}$ & Duration & $\begin{array}{c}\text { CWR } \\
\text { irrigatio } \\
n\end{array}$ & $\begin{array}{l}\text { Defic } \\
\text { it }\end{array}$ & $\begin{array}{l}\text { Surplus } \\
\text { Qty. }\end{array}$ & \\
\hline & & $\underset{\mathrm{s}}{\text { Cumec }}$ & Days & $\mathrm{Mm}^{3}$ & $\underset{\text { th }}{\operatorname{lpm} / \mathrm{mon}}$ & $\begin{array}{l}\text { Days/deca } \\
\text { de }\end{array}$ & $\%$ & $\mathrm{Mm}^{3}$ & $\mathrm{Mm}^{3}$ & $\mathrm{Mm}^{3}$ \\
\hline July Rice 135 day av. Rainfall & $\begin{array}{l}50 \% / \\
\text { Kharif }\end{array}$ & 0 & 0 & 0 & 48.0 & $10-1$ & $50 \%$ & 2.89 & 0 & \\
\hline July Rice 115 day av. Rainfall & $\begin{array}{l}50 \% / \\
\text { Kharif }\end{array}$ & 0 & 0 & 0 & 47.2 & $10-1$ & $50 \%$ & 2.84 & 0 & \\
\hline $\begin{array}{l}\text { August Rice } 135 \text { day av. } \\
\text { Rainfall }\end{array}$ & $\begin{array}{l}50 \% / \\
\text { Kharif }\end{array}$ & 1 & 25 & 2.16 & 0 & 0 & $50 \%$ & 0 & 2.16 & \\
\hline $\begin{array}{l}\text { August Rice } 115 \text { day av. } \\
\text { Rainfall }\end{array}$ & $\begin{array}{l}50 \% 1 \\
\text { Kharif }\end{array}$ & 1 & 25 & 2.16 & 0 & 0 & $50 \%$ & 0 & 2.16 & \\
\hline $\begin{array}{l}\text { September Rice } 135 \text { day av. } \\
\text { Rainfall }\end{array}$ & $\begin{array}{l}50 \% / \\
\text { Kharif }\end{array}$ & 2.19 & 30 & 5.68 & 0 & $10-3$ & $50 \%$ & 0 & 5.68 & \\
\hline $\begin{array}{l}\text { September Rice } 115 \text { day av. } \\
\text { Rainfall }\end{array}$ & $\begin{array}{l}50 \% / \\
\text { Kharif }\end{array}$ & 2.19 & 30 & 5.68 & 0 & $10-3$ & $50 \%$ & 0 & 5.68 & \\
\hline $\begin{array}{l}\text { October Rice } 135 \text { day av. } \\
\text { Rainfall }\end{array}$ & $\begin{array}{l}50 \% 1 \\
\text { Kharif }\end{array}$ & 0.77 & 28 & 2.12 & 36.2 & 31 & $50 \%$ & 2.18 & 0.06 & \\
\hline $\begin{array}{l}\text { October Rice } 115 \text { day av. } \\
\text { Rainfall }\end{array}$ & $\begin{array}{l}50 \% / \\
\text { Kharif }\end{array}$ & 0.77 & 28 & 2.12 & 17.3 & 31 & $50 \%$ & 1.04 & 1.08 & \\
\hline Total & & & & 19.92 & & & & 8.95 & 16.76 & $=10.97$ \\
\hline
\end{tabular}




\section{Estimation of crop water requirement (CWR)}

The water requirement can be defined as the amount of water, regardless of its source, that is required by a crop or diversified pattern of crops in a given period of time for its normal growth under a field conditions at a place. In CROPWAT 8.0 the calculation of crop water requirements is carried out by using crop coefficient approach. Crop coefficients used for paddy are presented in table 2. Crop water requirement of paddy were estimated from meteorological data using Penman Monteith method (CROPWAT 8.0). Programme allows the developed Schedules for different management conditions and the calculations of scheme water supply for varying cropping patterns. It also helps for improving irrigation practices and planning of irrigation schedules under varying water supply conditions.

\section{Estimation of net irrigation requirement (NIR)}

NIR estimation was done from the values of reference crop evapotranspiration $\left(\mathrm{ET}_{\mathrm{o}}\right)$, potential crop evapotranspiration $\left(\mathrm{ET}_{\mathrm{c}}\right)$ and effective rainfall. In present study CROPWAT 8.0 software was used for computation of crop ET and irrigation water requirement. Following relationship was used to determine $\mathrm{ET}_{\mathrm{c}}$ values of different crops:

Formula Etc $=\mathrm{K}_{\mathrm{c}} * \mathrm{ET}_{0}$

Where,

ETc $=$ potential crop evapotranspiration $(\mathrm{mm})$

$\mathrm{Kc}=$ crop coefficient for a given crop and

$\mathrm{ET}_{0}=$ reference evapotranspiration $(\mathrm{mm} /$ day $)$ check unit
The Net Irrigation requirement (NIR) of crop can be estimated from the following equation

$\mathrm{NIR}=\mathrm{ET}_{\mathrm{C}}-\mathrm{ER}$.

Where,

$\mathrm{NIR}=$ net irrigation requirement in a given month, $\mathrm{mm} /$ month

$\mathrm{ER}=$ Effective rainfall in a given month, $\mathrm{mm} / \mathrm{month}$

\section{Irrigation scheduling by CROPWAT 8.0}

In order to get optimized irrigation scheduling for efficient canal operations CROPWAT 8.0 requires all the informations pertaining to climatic data, soil factors and crop factors. The model was operated and results obtained are presented in table 3 .

\section{Results and Discussion}

The CROPWAT 8.0 was used for obtaining an optimized canal irrigation schedule for paddy (rice) crop of different maturity duration which is shown in table 3 . The optimized irrigation schedule obtained by CROPWAT 8.0 could result in saving of 8.95 $\mathrm{Mm}^{3}$ water. However, this is in the condition when the system of water distribution and intake is at its maximum efficiency. In present field scenario of study area the efficiency could be $60 \%$ only. Hence, to supply 8.95 $\mathrm{Mm}^{3}$ the system has to provide $14.91 \mathrm{Mm}^{3}$ therefore the actual surplus will be $5.01 \mathrm{Mm}^{3}$.

On the other hand, the efficiency can further be increased by adoption of modern techniques like laser land levelling and other field water management techniques, also project. This saved amount of water during kharif season can be utilized for growing rabi crops in the command area of right bank canal and also utilized to store in different village 
tanks, farm ponds etc. For public utilization, domestic purposes, horticulture and other uses in case of late monsoon in future and in emergency usage.

In practical conditions the efficiency of canal system to supply water is as maximum as $60 \%$. Due to that reason it is essential to consider the efficiency of canal irrigation system while supplying water for irrigation in the field. The optimized kharif crop water requirement is found to be $8.95 \mathrm{Mm}^{3}$ as surplus. To supply this much amount of water, System has to supply $14.91 \mathrm{Mm}^{3}$ of water to fulfill the Crop water requirement of the study area and the surplus amount of water can be utilized for Rabi season.

\section{References}

Doorenbos, J., and Pruitt, W. O. (1977). "Guidelines for predicting of crop water requirements". Irrig. Drain. Paper No.
24, Food and Agricultural Organization of United Nations, Rome, Italy.

Martin S., Richard G.A., Luis, Pereira, S and Raes, D. 1993, CROPWAT. FAO, Irrigation and Drainage, paper No. 49, FAO, Rome.

Mountonnet, P.2002, Yield reposnses factors of field crops to deficit irrigation. Irrigation and drainage. 22:37-43.

Rao, J.D. and Trivedi, S.A. 2012. Managing irrigation canal system with optimum irrigation scheduling for watrak irrigation scheme of north Gujarat. Journal of Engineering Research and Studies 3:5-27.

Singh, A.K., Verma, C.I., Singh, Y.P., Bhardwaj, A.K., Arora, Sanjay, and Singh, D. 2016. Irrigation water and pumping energy use trends in rice (Oryza Sativa L.) Under varying irrigation regimes in partially reclaimed sodic soils, Journal of Soil and water conservation 15(1):52-57.

\section{How to cite this article:}

Janhavi, Jitendra Sinha, Pushpendra Kumar Singh and Tripathi M. P. 2019. Assessment of Water Requirement and Irrigation Schedule for Right Bank Canal Command of Shahid Veer Narayan Singh Dam using CROPWAT 8.0. Int.J.Curr.Microbiol.App.Sci. 8(12): 2676-2682. doi: https://doi.org/10.20546/ijcmas.2019.812.313 